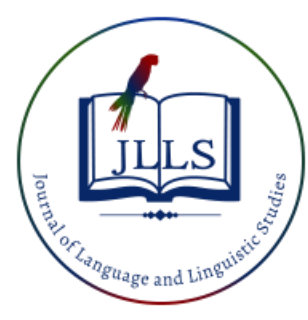

Available online at www.jlls.org

JOURNAL OF LANGUAGE

AND LINGUISTIC STUDIES

ISSN: 1305-578X

Journal of Language and Linguistic Studies, 17(1), 575-590; 2021

\title{
The formulation and generation of terms for phonetics and phonology in the
}

\section{Classical Arabic linguistic treatises}

\author{
Hamood Mohammed Alrumhi a 1 \\ ${ }^{a}$ Sultan Qaboos University, Muscat, Oman \\ ${ }^{a}$ University of Leeds, Leeds, UK
}

\section{APA Citation:}

Alrumhi, H.M. (2021). The formulation and generation of terms for phonetics and phonology in the Classical Arabic linguistic treatises. Journal of Language and Linguistic Studies, 17(1), 575-590. Doi: 10.52462/jlls.39

Submission Date: 11/01/2021

Acceptance Date: 19/03/2021

\begin{abstract}
This study seeks to uncover the theoretical bases for the production of the classical Arabic phonetic terms and their elements in the means of generating terms for both lexical semantics and conceptual semantics. The research problem is concerned with examining the roots of generating these phonetic terms and determining the categories of their elements in order to inspect the development of the generation of the terms and investigating the relationship between the specific lexical meanings and their change to figurative meanings. The study is based on the content analysis in terms of classifying the elements and analysing the roots of the qualitative data at the level of the features of the generation of terms' procedures. The findings indicate that the classical phonetic terms were subject to the parameters of the morphological derivation and based on three categories ranging from simple, to complex and compound, in addition to the change of the lexical meanings of the terms to figurative meanings. The study suggests linking the elements and methods of generating these phonetic terms with their partial and detailed definitions in these treatises. This is due to the interest of the ancient phoneticians in the explanation of the concepts more than the formulation of the terms.
\end{abstract}

Keywords: Arabic; classical phonetic terms; ancient Arab linguists; formulation; methods

\section{Introduction}

The study of the methodology of the Classical Arabic linguistic treatises in the production of phonetic terms and relevant issues is crucial for understanding how these treatises created a common language for phonetics. This can be done by identifying the connotations of these terms and recognising their roots, which in turn reduces disagreement between researchers on these topics. The word 'term' itself implies a linguistic unit that refers to a specific concept within a field of knowledge, agreed upon by specialists. The aim of this article is not to track the historical development of Classical Arabic phonetic terminology but to identify the methodology underpinning these terms through the following points:

\footnotetext{
${ }^{1}$ Corresponding author.

E-mail address: hamood@squ.edu.om
} 
1- The structure of Classical Arabic phonetic terms

2- The components of Classical Arabic phonetic terms

3- The methods of generating Classical Arabic phonetic terms

After the analysis of these issues, the study reaches conclusions that clarify the methodology underpinning the Classical Arabic phonetic terms and ways of generating them on the one hand and their most important elements in these treatises on the other.

\section{The structure of Classical Arabic phonetic terms}

Specialists are typically careful to devise their terms and expressions indicating certain concepts with elements of words compatible with the morphological system of a language (Colless, 1967; Wang \& Emurian, 2005). This issue focuses on the structure of the word and on the relevant morphological changes and additions resulting in a change in the semantics or function of these words. The word structure of phonetic terms in Arabic is based on morphological combinations giving shape to these terms in their various forms such as nouns, verbs, and their derivations so that they are meaningful expressions referring to specific concepts in a particular scientific field (Bauer, 2003). These morphological combinations depend mostly on the derivation processes characteristic of Arabic in generating many words from one morphological root then adding a group of prefixes and suffixes, leading to the multiplicity of combinations, each of which has a different denotation (Plag, 2012). Through the derivation process, the Arabic language academies have, in recent years, managed to devise Arabic words that can be used to express new concepts in the humanities and scientific disciplines which did not exist in the Classical Arabic dictionaries, these being limited to a specific time (Ḥiğāzī, 2018).

Phonetic studies in the Classical Arabic linguistic treatises did not focus much on the theoretical side of developing of terms or classifying their morphological structures. However, the terms and expressions which they used, and sometimes invented, did not violate the rules of Arabic in any of its linguistic branches, because these grammarians still retained the linguistic intuitions of native speakers and were not influenced by mixing with other linguistic cultures in the early Hijri centuries.

The methodology for the production of phonetic terms in the Classical Arabic treatises took various forms and was not limited to specific formulations. This variety in the formulation of Classical Arabic phonetic terms was conditioned by adherence to the rules of Classical Arabic morphology such that these terms were compatible with the morphological patterns of Arabic, and adhered to the rules of derivation that are based on deriving one word from another by changing the pattern while sharing a single root, with its general meaning. The structure of Classical Arabic phonetic terms varies according to standard features of Arabic such as those involving the 'ism 'noun', harf 'letter', șawt 'sound' and ğars 'tone' (Al-Farāhīdī, 2003, 1/ p. 231, 305, 2/ p. 421) or the formulation of the mașdar

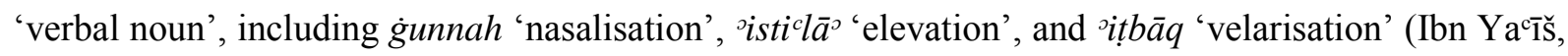
2001, 5/ pp. 522-524). The plural form is these terms is used when referring to a group of features, such as hurūf (letters), 'așwāt (sounds) and harakāt 'short vowels' (Al-Farāhīdī, 2003, 1/ p.305, 2/ p. 421). Some phonetic terms took the form of nominal derivations like the active participle, for example, sākin, mutaharrik, andmunharif, while others involved the passive participle such as mahmūs, mağhūr, and mukarrar (Sibawayh, 2015, 5/ pp.730-733), and yet others a locative noun such as mawḍic,maxră̆, madră̆ (Al-Farāhīdī, 2003, 1/ p. 34, 36, 41; Sibawayh, 2015, 5/ pp. 728-730). Additionally, as a result of derivation processes that are widely used in Arabic, some of these terms change from the form of nouns to that of verbs in order to suit the context of the explanation and clarification of the definitions of these phonetic terms. Thus, istițalah has the verb form yastatìl, and tafašš $\bar{l}$ has the verb form yatafašš $\bar{a}$ (Būrūbah, 2006). These changes of the form between nouns and 
verbs through derivation do not mean a difference in the denotations of the relevant Classical Arabic phonetic terms; simply that they were characterised by morphological flexibility in the structure of the word which in no case leads to confusion as to their definition and purposes. The following table (1) illustrates the previous examples of the different formulations of Classical Arabic phonetic terms in these treatises.

Table 1. Different formulations of Classical Arabic phonetic terms

\begin{tabular}{|c|c|c|c|c|}
\hline \multirow[t]{2}{*}{ Simple noun } & \multirow[t]{2}{*}{ Verbal noun } & \multicolumn{3}{|c|}{ Nominal derivation } \\
\hline & & Active participle & Passive participle & Locative noun \\
\hline șawt & $\dot{g} u n n a h$ & sākin & mahmūs & mawdị \\
\hline harf & ${ }^{o}$ isticla $^{\supset}$ & Mutakarrir & maǧhūr & maxrằ \\
\hline ğars & oițāa & munharif & mukarrar & madră̌ \\
\hline
\end{tabular}

In the methodology of the Arabic linguistic treatises, what seems to facilitate the goal of adhering to the rules of morphology in the structure of these terminological expressions is the fact that all the phonetic terms in these treatises are of Arabic origin. Numerous Arabic phonetic terms in contemporary studies might need to be borrowed from other languages, such as 'allophone', 'phoneme' and 'morpheme' (Abd Al-Ğalīl, 1997, pp. 97-183). By contrast, the structures of the Classical Arabic phonetic terms are part of the pure Arabic environment and they are not borrowed from other languages like Persian or Sanskrit which were used in areas geographically close to the Arabian Peninsula during that period. In addition, while contemporary Arabic phoneticians have relied on translation for many phonetic terms such as 'acoustic response', 'nasal resonance' and 'vowel harmony' (Johnson, 2011), translation was not a source of the structure of the Classical Arabic phonetic terms. The Arabic phonetic terms utilised in the Classical Arabic linguistic treatises in developing the definitions of speech organs like șadr 'chest', halq 'throat', lisān 'tongue' and the places of articulation of sounds like tabaqī'velar', $\dot{g} \bar{a} r \bar{\imath}$ 'palatal', and šafawr 'bilabial', and the manners of articulations such as ğahr and hams, and šadìd and raxw are from Arabic roots that were used for general concepts, as mentioned in the Classical Arabic dictionaries, before being adopted as specialist terms in the field of phonetics.

Some contemporary studies have argued that the phonetic topics addressed by the Classical Arab grammarians were influenced by previous phonetic studies of the Indians and Greeks (Versteegh, 1977; Troupeau, 1982). Assuming the validity of this view, the structure of the Classical Arabic phonetic terms was not included in that circle of influence (Zawāqirī, 2017). Despite the temporal precedence of the Sanskrit grammarians and the Greek philosophers in phonetic studies of their languages over the ancient Arab linguists (Semaan, 1968), this precedence is not sufficient evidence to demonstrate the influence of their phonetic studies on the Arabs particularly in the early Hijri decades during which there were no available translations in the Arabic treatises.

Therefore, if there was an influence from non-Arabic cultures then, as argued by E. Littman, this influence seems to have come later, after the book of Sibawayh through translations that appeared in the fourth Hijri decade (Fleisch, 1961).Consequently, the phonetic terms employed by Al-Khalīl Ibn `ahmad and Sibawayh were used at a stage preceding the influence of other languages and cultures and translations therefrom. Although there was a significant debate before Al-Khalīl and Sibawayh between supporters and opponents of this influence, what matters most in this context is that the Classical Arabic phonetic terms and their concepts in these treatises in the chapter on ${ }^{\circ} i d \dot{g} \bar{a} m$ share the following traits: 
1- All the phonetic terms and expressions are formed from Arabic roots which Classical Arabic dictionaries outlined and whose linguistic origins they demonstrated. There are no foreign phonetic terms adopted in these treatises.

2- The linguistic sources that these treatises relied on for phonetic topics are Arabic sources involving Arabic dialects, the Quran, and Classical Arabic poetry. There are no examples from non-Arabic sources for the analysis of phonetic topics.

3- The scholars of Arabic who established the earliest terms for phonetic rules all grew up in Arab environments even though some were of non-Arab origin. There are no linguists in these treatises from the Indian or Greek cultures which had temporal precedence in studying phonetic topics.

Accordingly, there appears to be no influence of non-Arabic cultures on the structure of the Classical Arabic terms in the Classical Arabic linguistic treatises, particularly the phonetic terminology used by Al-Khalīl Ibn ${ }^{\circ} \mathrm{Ahmmad}$ and Sibawayh. Even if the influence of other cultures could be proved, such influence is limited to the ideas and methodology of phonetic studies in phonetic topics such as the places and manners of articulation, rather than applying to the structure of phonetic terms. Some linguistic treatises that were written after Sibawayh's time made sure to take the same terms used by Kitāb Sibawayh 'the Book of Sibawayh'; and several of these treatises took what Sibawayh wrote on phonetic topics without changing the content or using synonyms in their explanation, as, for example, Ibn As-Sarrāğ (Ibn As-Sarrāğ, 1996, 3/p. 399-401). All of this reflects the wide influence of and dependence upon Al-Khalīl Ibn ${ }^{\circ} \mathrm{Ahmmad}$ and Sibawayh in subsequent linguistic treatises in particular regarding phonetic terms.

\section{The components of Classical Arabic phonetic terms}

Classical Arabic phonetic terms are each composed of one or several words taken from linguistic or non-linguistic fields in accordance with expressions agreed upon by specialists for these terms, and convey certain concepts in certain fields of knowledge. Specialists resort to devising terms for words related to concepts that need an independent term and bearing their own definition and which are compatible with the concepts they denote. This requires understanding the term both as used in the language in general and in the specific field of study (Laprie, 1992). While the Classical Arabic phonetic terms varied in their morphological roots and derivations, as analysed and detailed in the previous section, these terms can all be analysed either as simple one-word terms, compound twoword terms, or complex terms involving more than two words. The components of the terms are thus divided into three categories as shown in the following table (2).

Table 2. Components of the terms

\begin{tabular}{|l|l|l|}
\hline Simple terms & Compound terms & Complex terms \\
\hline formed of one word & formed of two words & formed of more than two words \\
\hline
\end{tabular}

Although single-word terms are more common than compound two-word terms, and the latter are more common than complex compound terms made up of more than two words, it does not follow that there is a preference of one form over the other. The basis of the linguistic structure of the term is that it is related to a specific concept in the specialised field, bearing in mind that the morphological features of Arabic more than anything else allow for a specific form of the word in different contexts, as is common with respect to Classical Arabic phonetic terms. However, this facilitation did not prevent the existence of both general and specific phonetic terms composed of compound or complex elements, in particular phonetic terms in contemporary phonetic studies, as compared to Classical Arabic phonetic studies (Khālidīi, 2012). 
Through the plurality of these elements, the phonetic terms were developed in the Classical Arabic linguistic treatises despite the absence of theoretical principles for formulating these linguistic terms. It seems that the ancient Arab linguists focused more on explaining concepts than on developing terms because of the strength of their linguistic intuition and the employment of expressions from their own Arab environment rather than from translations or other languages. The majority of the words used in these phonetic terms in these treatises were familiar in the daily discourse of Arabs before becoming terms signifying specific denotations in the field of Arabic phonetics. The Classical Arabic phonetic terms are sometimes abbreviated in later works using a single element of what was originally a compound expression in an earlier treatise.

It seems that some of the denotations of these concepts are also not limited to a single element. Therefore, the ancient Arab linguists were compelled to develop terms with several elements, whether these be compound or complex. It is possible through the examples in these treatises to explain the division of these elements into these different categories. The following table (3) presents examples of the elements of phonetic terms in the methodology of the Classical Arabic linguistic treatises (AlFarāhīdī, 2003, 1/ p.34, 36, 41; Sibawayh, 2015, 5/ pp.728-730; Ibn As-Sarrāğ, 1996, 3/p. 399-401).

Table 3. Elements of the Classical Arabic phonetic terms

\begin{tabular}{|c|c|c|}
\hline $\begin{array}{c}\text { Terms involving simple } \\
\text { elements }\end{array}$ & $\begin{array}{c}\text { Terms involving compound } \\
\text { elements }\end{array}$ & Terms involving complex elements \\
\hline$n a b r$ & an-nūn al-xafı̈fah & hamzat bayna bayna \\
\hline rawm & $a d ̣-d ̣ \bar{a} d a d+d a^{c} \bar{\imath} f a h$ & aš-šin al-latī kal-ǧìm \\
\hline `išmām & 'alif at-tafxim & aș-șād al-latīkaz-zāy \\
\hline madd & ${ }^{\circ}$ alif al-`imālah & al-kāf al-latī bayna al-ǧ̀̃m wa al-kāf \\
\hline maqta ${ }^{c}$ & ḥurūfal-mu'ğam & aș-șād al-latīkas-sīn \\
\hline qalqalah & șawt aṣ-șadr & 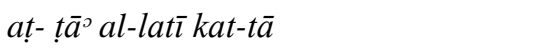 \\
\hline șafir & șawt al-fam & bayna ar-raxwah wa aš-šadìdah \\
\hline
\end{tabular}

The terms in Table (3) are merely examples of each category; the table does not, of course, present a comprehensive list of phonetic terms belonging to these three categories in the Classical Arabic linguistic treatises. Although the introduction to the chapter on idg $\bar{a} m$ chapter in these treatises is short, terms with their different elements are common in many parts of this chapter. Terms composed of one element are most common, followed by terms of two elements and lastly those composed of more than two elements. It is possible, based on the categories illustrated in table (3) above, and the previous discussion to arrive at valuable findings regarding the Classical Arabic phonetic terms, as follows:

1. It seems that most of the Classical Arabic phonetic terms consist of one element because of the ease that all linguists seek in various disciplines in respect of brevity and conciseness, particularly if the element has a clear relationship to the concept that it refers to using one word. This facilitates the use of its derivations for explanation and clarification.

2. There are a number of Classical Arabic phonetic terms consisting of two elements that have a morphological link between them via connecting words, such as al-mudāf wa al-mudāf `ilayh 'the possessor and possessed' or aș-șifah wa al-mawșüf 'adjective and described' (Versteegh, 1993), the 
result being one specific linguistic concept. Splitting these two components leads to a difference in the meaning of the phonetic terms.

3. Some Classical Arabic phonetic terms involve complex elements that have a detailed analytical denotation, in order to accurately clarify the term concerned, avoiding confusion with other terms. These terms were formed through expressions with two key roles. The first is that of identifying the phonetic concept through the basic phrase elements such as nouns and verbs. The second is the expressive role of clarification through the secondary elements of a phrase such as conjunctions and prepositions.

Where a Classical Arabic phonetic term consists of different elements, this might have come about at the stage of the establishment of the phonetic term because of the feeling that a single element was not sufficient to convey the intended meaning of the phonetic concept. Following that, these phonetic terms sometimes developed, through abbreviation or replacement, from complex terms to compound ones, and then even from compound terms to simple ones, as a result of the search for synonyms. This is the case, for example, with the term hamzat bayna bayna, which was reduced to two elements by later grammarians and linguists, who used the terms hamzat at-tashil or hamzah musahhalah. (AsSiyūṭị, 2001, 6/ p. 289). Similarly, Sibawayh's term baynaar-raxwah waaš-šadìdah, in later treatises became the single word 'isticānah in Al-Mubarrid (285 AH/ 899 CE) (Al-Murādī, 1987, 1/p. 196) and muctadil in As-Sakkākī (626AH /1160 CE) (As-Sakkākī, 1987, p.12). The term mutawașșit is considered among the most common of these terms in other treatises (Al- ${ }^{-} a n d a l u s i \overline{1}, 1998,1 / \mathrm{p} .5$ ). This term was used on the basis to indicate an intermediate articulation between two (major) manners of articulation.

\section{The methods of generating Classical Arabic phonetic terms}

In addition to the variety of Classical Arabic phonetic terms in respect of their elements and forms as previously detailed, these terms vary in their meanings much like other terms in linguistics. This variation takes two forms: the first may be termed 'lexical semantic' and the second 'conceptual semantic'. The first, lexical-semantic, carries the general meaning of the term and the various less stable associated meanings since it is possible that these may change and develop from one context to another. This includes different meanings of the term which may be familiar in a daily conversation between native speakers as given in non-specialised dictionaries (Ramchand \& Svenonius, 2002, pp. 387-400). The second, the conceptual semantic, carries the specific meaning of the term whose significance cannot change from one context to another as it is connected with a fixed meaning within a specific lexical field and is defined in specialised dictionaries of the relevant field (Pinker \& Levin, 1991). There is a difference between the semantics of the term in its lexical-semantic sense, which is spontaneous in the use of the speakers of the language, and the later limited conceptual-semantic terminological sense which is associated with prior awareness by specialists of a specific field. There is a connection between lexical semantics and conceptual semantics at the level of terms when there is a similarity between at least one of the lexical-semantic senses and the conceptual-semantic sense, it not being necessary that the conceptual-semantic sense be related to all the lexical-semantic senses (Murphy, 2003). Therefore, several Classical Arabic phonetic terms shifted from their general sense(s) in the use of speakers to a specific phonetic sense for linguists and became key terms shared by all those interested in phonetic topics as they are among the basic terms of the research area, and a lack of precision in the definition of these terms would undoubtedly lead to a lack of precision in their use.

Generally, changes in terms may arise in various ways and are not limited to a shift from a general lexical sense to a specific terminological one. Terms have a variety of origins, and it is not necessary to a invent a new word for a concept that was not previously known; indeed, many of the specialised 
terms are, in their origin, common words but have different senses to those found in everyday language. In addition to the earlier sources mentioned for producing new terms, terms can be generated through the use of (Kockaert \& Steurs, 2015; Alwin \& McCammon, 2007):

1- Portmanteau words to shorten multiple words, yielding one word in a simple element.

2- Borrowing from other languages, especially if the term is common in those languages.

3- Translation of a foreign term using Arabic words which cover the meaning of the non-Arabic term.

4- The use of figurative language by changing the basic sense of the original word to a figurative sense, there being a clear link between the two meanings.

5 - Change in the sense of the word to another meaning not referred to in dictionaries. Contemporary studies specialising in terminology have developed various theoretical approaches for generating terms, distinguishing in particular between the traditional terminological approach and the lexicographical approach (Karpova \& Kartashkova, 2009). The traditional terminological approach is sometimes called 'onomasiological'. It starts with the concept and then seeks a suitable name. By contrast, the 'lexicographical approach' is sometimes termed 'semasiological'. This starts with a word and then considers the meanings and concepts it may denote (Grondelaers \& Geeraerts, 2003). Arguably, both the onomasiological and semasiological approaches may be found in the generation of the Classical Arabic phonetic terms. These terms do not fit under one approach, at least in part reflecting the fact that the terms themselves were produced over a long period. In many cases it is difficult to determine when the term's development first began, and the method used to develop these terms may only be determined through speculation rather than from conclusive evidence. The criteria identified by contemporary studies specialising in terminology for the norms of generating terms are mostly compatible with the structure and elements of the Classical Arabic phonetic terms. The majority of these requirements, such as accuracy, direct connection with the concept and being monosemic, a lack of homonyms, and lack of morphological variants (Sager, 1990), are applicable to several Classical Arabic phonetic terms. At the same time, there are Arabic phonetic terms that do not meet the requirements of the generating process because of the variety of phonetic terms for one concept compared to the variety of concepts for one phonetic term in the Classical Arabic linguistic treatises.

In their methodology, the ancient Arab linguists did not use all these methods of generating Classical Arabic phonetic terms, especially the early linguists in the second Hijri centuries like AlKhalil Ibn ${ }^{\circ}$ Ahmadand Sibawayh, who had a clear influence on the subsequent grammarians. The noticeable characteristic of the methodology of the Classical Arabic treatises in the generation of Arabic phonetic terms is that they are all of Arab origin, with no borrowed terms from other languages or translations (calques). Despite the numerous methods of generating terms, it seems that the salient feature in the transition of Classical Arabic phonetic terms from general lexical senses to the specific phonetic concept in the methodology of the Classical Arabic treatises occurs through two basic methods: 1. specification of existing lexical sense; and 2. transfer to figurative sense. Through these two methods, it is possible to clarify the relationship of Classical Arabic phonetic terms with their senses, whether they are basic senses or figurative senses. These two means differ in generating the Classical Arabic phonetic terms in terms of their frequency of use. This becomes clear through the examples of each category along with the discussion of the relationship of the phonetic terms with their associated senses.

\subsection{Specification of existing lexical sense}

Most words have multiples senses in general dictionaries which are based on the usage of speakers of the language and the contexts in which they are put, leading to a diversity and growth of the number 
of denotations according to their relevant fields and areas. The relation between the relevant general sense of a word and the denotation of the specific term is not based on the full agreement in meaning, nor on randomness in adopting any meaning without a link between the preceding sense and the concept specific to the word as a technical term (Kilgarriff, 2007, pp. 29-46). The general senses of the words of a language are devised and created in an impromptu environment without any prior planning and restrictions on the part of native speakers. However, the situation is different when these words develop technical senses because their creation is based on a prior awareness of specialists in choosing a word as a term for a specific concept. The allocation of a technical sense is decided by a change from numerous usages of the word which apply in different contexts, to a specific significance for a specific concept that cannot be confused with another meaning. When a word becomes a term in a particular field, there is a change in its general meaning(s) into a specific terminological sense that does not share anything with the other previous senses of the word (Meyer \& Skuce, 1997, pp.98-119). Thus, before becoming a term, a word may have multiple general senses but is then allocated to one technical sense as a result of the transition to a field of terminology which requires precision in its use of concepts (Uschold, 1998, pp.5-29). This method of generating terminology is related to the concept in order to distinguish it from other senses, and inaccuracy in the selection of the term will inevitably lead to inaccuracy in its use. Classical Arabic phonetic terms of this kind have been transformed from general units to precise units in the field of phonetics that do not allow shared meanings or multiple denotations.

In addition to linguistic precision in allocating lexical senses in generating terms, there are other requirements such as concision, because several terms may be generated only because there was a relation of similarity between a general lexical sense and the terminological denotation without any need for a relationship between the terminological sense and all the general lexical senses of the word (Rey, 1995). Concision is not synonymous with precision but must be associated with the clarity of the term, since concision requires that it should not affect the concept denoted by the term. Most Classical Arabic phonetic terms are composed of one or two elements for the sake of brevity and concision in their components. These terms also avoid detailed description, sometimes because of the clarity of a term composed of only one element. Despite the importance of brevity and concision in generating terms through the re-allocation of existing lexical senses, some Classical Arabic phonetic terms are composed of complex elements as a result of the inability of one element to clarify what is intended by these terms, as previously pointed out. What matters most in this context is that concision is common in generating Classical Arabic phonetic terms but cannot be prioritised over the accuracy of the term because the basic sense of one element cannot be found in the concept expressed by the phonetic term. The basic sense of the term hamzah, '[act of] prodding/goading', differs from the sense it has in the term hamzat bayna bayna, 'the hamzah [glottal stop, etc.], which is in-between' (Vallaro, 1987, pp.215-221). For this reason, two other elements were added in this term to make it more specific than the more basic sense.

While Classical Arabic phonetic terms were developed on the basis of the principles of hearing, acoustics, and articulation in the Classical Arabic treatises, these terms in fact have their previous roots in the multiple senses of the words which existed before they became part of the field of phonetics. Several ancient linguists and grammarians mentioned the primary lexical senses of some of the terms for phonetic concepts. For example, Abu Sacidsirä́fı (368 AH, 978 AD) clarified the reason for choosing the term tarxim, especially when associated with the sound 'alif, where it is termed ${ }^{\circ}$ alifattarxim, which is one of the allophones of the sound (phoneme) 'alif (As-Sīrāfĩ, 2008, 5/. p.388). The meanings of the word tarxim in general Arabic dictionaries have to do with softness and gentleness, and by extension flattery and facilitation. Abu SacidSìräfi attributes the origin of the term 'alifat-tarxìm to a reduction in the volume of the sound, because when ${ }^{\circ}$ alif is characterised by this quality the sound becomes soft and gentle and the degree of loudness decreases. Therefore, ${ }^{\circ}$ alifat-tarxim became a term for this sound. This term was re-allocated in the field of phonetics to describe a group of sounds that have the quality of tarxim , which has subsequently become known as at-tarqīq 'softening' (Aș-Ṣiyag, 2000, p.150). By contrast, other sounds not involving this manner of articulation are typically referred to by the term tafxim, whose general meanings revolve around reverence and veneration, as well as having a specific sense in the field of phonetics where it is used to refer to several sounds which have a strong phonetic similarity (As-Sāmarrā̄ī 2011, p.145). The same happened with the term ${ }^{\circ}$ ixtilās, 
which is used in the sense of uttering a vowel quickly in such a way that the listener thinks the speaker did not utter it, especially a short vowel which cannot be heard by all listeners (Al-cUbaydī, 2007, p.22). In fact, the choice of this term for this process of speaking quickly through shortening the duration of the vowel to the degree that the listener does not recognise it is explained by the more basic sense of this term which revolves around stealing things stealthily. In their analysis of the senses of this word, general dictionaries refer to the fact that fast speaking and reading leads to an ambiguity in some sounds. Therefore, the ancient Arab grammarians and linguists allocated this term in the field of phonetics to a rush in articulating short vowels in such a way that a third of the vowel is omitted leaving just two-thirds of it pronounced. This contrasts with the term ${ }^{2} i s ̌ b \bar{a}^{c}$ which is used to signify making a short vowel longer so that it becomes a long vowel (Aș-Ṣiyag, 2000, p.233). There is another phonetic term, rawm, which has in common with the previous term ${ }^{2} i x t i l a \bar{s}$ a decrease in the length of a vowel when uttered during continuous speech (As-Sāmarrā̄ $\overline{1}$, 2011, p.365). However, the ancient linguists distinguished between ixtilās and rawm. They defined rawm as occurring on the last vowel of a word in the case of pause and being specific to the two vowels dammah (u) and kasrah (i), through the omission of two-thirds of the length of the vowel, leaving one third. 'ixtilass, by contrast, occurs in all short-vowel positions in the word and is not limited to pause through the inclusion of only two-thirds of the length of the vowel (Al-cubaydī, 2007).

These subtle differences were intended to distinguish between general lexical sense(s) covering various meanings and the specific technical sense following the transition of the word to signify a specific concept in the field of phonetics. The German orientalist Hans Wehr, to take an example, made a mistake when he interpreted the term ğaras to mean 'sound' in phonetics according to the ancient Arab linguists (Wehr, 1979). This term does not signify this concept; in fact the word șawt 'sound' for the ancient Arab linguists has a denotation which is different to that of garas, which is closer to 'tone of voice' (Al-Farāhīdī, 2003, 1/ p.231; Ibn Manẓūr, 2003, 3/124). While some Classical Arabic phonetic terms which were generated through the re-allocation of existing lexical meanings appear to have been shortened but are not precise or have not been shortened but show precision, the terms for short vowels in Arabic combine accuracy in their description of the physical articulatory process and concision, in that they are composed of only one element. The terms for the short vowels are compatible with their more basic lexical sense(s), especially in respect of the shape of the lips during the articulation of the relevant sound. Thus, the term for the short vowel fathah is taken from the opening of the lips forward, while the term dammah is derived from the rounding of the lips in the form of a small circle. The term kasrah is taken from the regression of the lips and their movement backward in the form of a smile on the face ('Utmān, 2010). The connotations that are linked to the terms for these short vowels have their origins in the general lexical senses of circling and joining of the lips in the case of dammah, opening and expansion in fathah and regression and moving backwards in kasrah. Later these words shifted their senses to specific ones, especially in terms of the short vowels of Arabic. The position of the tongue, whether it is high or low in the oral cavity, and the form of the lips, whether they are round or extended, are principles of the theory of cardinal vowels, first developed by Daniel Jones. This provides the general criteria for the manner of articulating vowels of all languages and is not linked to any specific language (Jones, 1976). These principles are the same ones that gave rise to the generation of the terms for short vowels in Arabic in the first and second Hijri centuries in the classical linguistic Arabic treatises.

From the discussion of the previous examples of Classical Arabic phonetic terms which appear to have shifted from general lexical senses to specific phonetic denotations, the following conclusions can be drawn:

1. Extending the uses of a word that bears multiple lexical senses so that it becomes a term that has also a specific technical sense was one of the means of generating terms used in the Classical Arabic treatises. Accordingly, this word came to signify its own specific concept in the field of phonetics and could not be confused with other senses.

2. The definition of terms in specialised fields contrasts with general lexical senses which differ from one environment and one group of speakers to another within a single language. General lexical senses are generated spontaneously without any prior planning according to the usage of the 
speakers of a language. By contrast, technical denotations of the term are generated with awareness and agreement between specialists as was the case with phonetic terms.

3. Extending these words so that they became technical terms through the re-allocation of lexical senses required norms and procedures, and most importantly accuracy and concision. While some Classical Arabic phonetic terms were not precise due to their confusion with other phonetic terms or as a result of variation in their elements, especially in their initial development, there are other terms which displayed both precision and concision, such as the terms for the short vowels in Arabic.

In general, generating terms through extending existing lexical denotations to a specific technical sense is one of the most common and easiest means for the development of terms. It is a means employed by the ancient Arab linguists and appeals to contemporary researchers in the field of phonetics because it is a straightforward means that does not have many requirements compared to other means of term generation.

\subsection{Transfer to the figurative sense}

General dictionaries seek to limit the senses of words, especially in social life, which is characterised by the interaction between speakers, starting from the nucleus of word senses, and then moving to other fields such as specialised fields. Despite the best efforts of specialists in general dictionaries to limit the senses of words, evolution in the use of words leads to a difficulty in restricting these words to their basic lexical senses as the usages of language shift in some contexts from 'literal' senses to figurative senses (Giora, 2002, pp.487-506). With figurative senses, words change from literal 'direct' senses to indirect ones via a connection that prevents an interpretation in the basic sense and a relation that links the basic sense of the word with the figurative sense (Gibbs Jr, 2001, pp. 317-333). In relation to terminology, this means that the basic sense of the word is shifted metaphorically to another new sense, leading to unlimited semantic evolution and allowing for unpredictable new denotations. Some researchers argue that the use of metaphor for developing technical terms reflects the fact that the number of words in languages is limited but the number of meanings is not, especially in relation to metonymy and metaphor which are linguistically concise and an important means of enriching vocabulary in respect of technical terms and the senses they convey (Darqāwī, 2016). Metaphorical Classical Arabic phonetic terms vary with respect to their corresponding basic senses, such as physical positions ranging from high to low and ethical behaviour ranging from appreciated to unappreciated. The basic senses are shifted, giving rise to phonetic terms signifying concepts through metaphors and other types of figurative language to expand the denotations of these words.

A very clear example of a term in Classical Arabic phonetics which was extended from a nonmetaphorical basic sense to a metaphorical technical sense is the word harf (basic sense 'edge, border'), which signifies a number of different concepts in the Classical Arabic treatises (Ibn Manzūr, 2003, 4/89). The term harf did not signify a single notion for the grammarians in the Classical Arabic linguistic treatises, particularly at the time of Sibawayh and those linguists who preceded him. This term has many senses in the field of phonetics and Arabic grammar and the Quranic readings as well as non-technical senses in non-specialist Arabic dictionaries. Within the field of phonetics in the Classical Arabic treatises, harf refers to two notions. The first of these is the written symbols for the consonant phonemes of Arabic, plus the long vowels the symbols for which overlap with those for the consonants, in contrast with the symbols for the short vowels which are marked above or below the symbol for the preceding consonant (Al-Farāhīdī, 2003, 1/ p.305). The second concept signified by the term harf in these treatises is the linguistic sound in the process of the production of speech, whether 
the basic pronunciation of a consonant or long-vowel phoneme, or the pronunciation of a 'secondary' allophone, as found in a particular Arabic dialect (Sibawayh, 2015, 5/ p.728). The overlap between the two concepts led many modern researchers to attempt to restrict the use of the term harf to denote the written symbol (grapheme) corresponding to a consonantal phoneme in Arabic, distinguishing it from the term șawt 'sound' in order to distinguish between the oral pronunciation and the written symbol (Al-Rumhī, 2004, pp. 21-25).

Despite the two senses of this term in phonetics, the general lexical sense has nothing to do with sounds or written symbols. The meaning of this word in Arabic dictionaries is given as the 'edge' or 'side' of something. This is found in the speech of the ancient Arabs and the Holy Quran and in the teachings of the Prophet in texts where the meaning clearly has to do with 'edge' or 'side', such as the sloping side of a mountain as mentioned by Classical Arabic dictionaries (Az-Zabīdī, 2001, 8/ p.23). The ancient linguists tried to link this general sense and the phonetic concept expressed by harf, by linking the 'edge' to the end of the breath at the places of articulation in pronouncing sounds (Ibn Ğinnī, 1993, 1/ p.14). Thus, the word harf 'letter' is the 'limit' of the spoken sounds. This linkage involves a similarity between a basic sense and its transition to a metaphorical sense, because sounds, by their nature, are not concrete or physical in the same ways as objects being different from material objects that have a boundary at their edges. Despite this attempt to link the two senses, this word in its other sense, which is the written symbol for the ancient linguists, has very little to do with the basic sense of harf. This can be explained by the fact that the basic and technical senses of this word have expanded.

A similar relationship exists between the basic sense of a word and its extended sense, when used to denote a phonetic concept, when Classical Arabic phonetic terms are generated through linguistic metaphor. The nomadic nature of the Arabian Peninsula had an impact on the transition of many words from their basic sense to a metaphorical sense in Classical Arabic phonetic terminology. This is evident in many of the terms denoting the manners of articulation of the phonemes of Arabic, which relate to various concepts and topics in the methodology of Classical Arabic grammatical treatises, especially in the chapter on idjām. As technical phonetic terms, šiddah as a noun and $\check{s} a d \bar{l} d$ as an adjective, contrasting with raxāwah as a noun and raxw as an adjective, refer to two manners of articulation (Sibawayh, 2015, 5/ p.730), corresponding roughly to notions of plosive and fricative sounds in contemporary phonetic studies (Watson, 2002). However, the basic sense of the term šiddah in general Arabic dictionaries is the solidity and sturdiness of strong bodies that cannot be easily dismantled (Ibn Manzūur, 2003, 8/ p.39). This word is also used to express the harshness of life, the severity of cold weather, and the severity of the disease, indicating unbearable difficulty. As a manner of articulation in phonetics, by contrast, the term šiddah indicates clear sonority as a result of the way the sound is produced through sudden airflow after a blockage in its place of articulation. Thus, it becomes clear that the transition of the word from its basic sense denoting solidity and sturdiness its the metaphorical sense in the precise description of sounds is a result of a relationship of similarity between the two senses.

The opposing term to šiddah in the classifications of the manners of articulation of the Arabic sounds is raxāwah, which refers to an opposing manner of articulation as previously mentioned. The distinguishing features of the 'intense' sounds involving šiddah include the inability to repeat them because they are produced momentarily and suddenly after complete stopping of the airflow. This can be compared to the distinguishing features of the raxāwah 'soft' sounds, which can be repeated and 'sung' because they are continuous in their production without any stoppage (Ibn Manzūr, 2003, 6/ p.131). In Arabic dictionaries, the senses given for the word raxāwah revolve around softness and weakness; thus bodies described using this word are soft and smooth (Az-Zabīdī, 2001, 38/ p.137). It seems that the similarity relates to weakness and powerlessness, in relation to physical things in their 
basic sense and the sounds in their metaphorical sense. The Arabic sounds that are characterised by a raxāwah articulation can be considered weak because the air in the place of articulation at the time of pronunciation is not propelled as strongly as with plosive sounds.

While the metaphorical expressions involving the preceding terms were associated with the strength and weakness of the manners of articulation of the Arabic sounds, the terms for the allophones of these sounds (phonemes) in these treatises were associated with human behaviour. The Classical Arabic treatises divided the allophones of the Arabic sounds (phonemes) into acceptable allophones, terming these hurūfmustaḥsanah (Az-Zağğăğ̄i, 1988, p.409), and unacceptable allophones, terming these hurüfmustaqbahah (Ibn Ya $\mathrm{Ya}^{\mathrm{i}} \mathrm{\textrm {s }}, 2001,5 / 518$ ). The second word in each of these two terms, mustahsanah and mustaqbahah respectively, has senses in general Arabic dictionaries associated with ethical aspects of human behaviour, depending on the nature of people, which differs from one environment to another in terms of accepting or rejecting such behaviour. These two terms were not originally used to describe allophones, but linguists developed figurative senses from them so that they became terms for aesthetic criteria in the classification of allophones.

All things considered, the earlier analysis of the examples of terms that have apparently shifted from basic lexical senses to metaphorical senses can lead to important results in this context. First, metaphorical extensions of words are one of the means of generating phonetic terms in the Arabic linguistic treatises by between the basic lexical sense and the later metaphorical sense of the term. Second, basic senses cannot be compared to metaphorical ones because basic senses are limited while metaphorical senses can multiply endlessly for many reasons such as the expansion of the horizons of linguistic use in daily interchange. It seems that the effect of nomadic life in the Arabian Peninsula and other areas such as Iraq and Syria had an impact on the generation of terms and their connection to the strength and weakness of the manners of articulation of Arabic sounds. Third, the description of human behaviour as either appreciated positive behaviour or unappreciated negative behaviour had an impact on the development of Classical Arabic phonetic terminology, especially in the division of the types of allophones in the ancient Arabic dialects. The terms used are, in their more basic senses, expressions to refer to ethical standards which then shifted through metaphorical senses to the classification of sounds according to the standards of the ancient linguists in accepting some dialects in the classical language and rejecting others.

The transition from basic to metaphorical senses is found in several terms in phonetics in the Classical Arabic treatises. The generation of terms in Arabic using this method is ongoing even in contemporary phonetic studies and other linguistic fields, as attested especially in specialised dictionaries which explain these senses.

\section{Conclusion}

The foregoing investigation of the methodology of the Classical Arabic linguistic treatises in the drafting of phonetic terms shows that this issue is surrounded by several controversies sparking discussion and disagreement between learners and researchers. The linguists and grammarians of the early Hijri centuries had the ability to develop terms using different derivations and to present concepts through various methods. However, they did not provide theories for these forms and differences. The current study has considered in detail the methodological issues related to terms and definitions in these treatises and reached a number of important conclusions, as follows:

1. Even though the linguistic and grammatical treatises in the first Hijri centuries were not concerned with the theoretical study of terms and their generation, the variety of the forms of terms and the multiple ways in which they were derived show that they were governed by the morphological rules of Arabic and were compatible with the linguistic intuition of the ancient 
Arabs, and were not influenced by other linguistic cultures. As well as obeying the rules of Arabic morphology, all the roots of the Classical Arabic phonetic terms are of Arabic origin and there is no trace of terms borrowed or translated from other languages. This indicates that preceding cultures which engaged in phonetic studies had no impact on the structure of the Classical Arabic phonetic terms, or on the ways in which they were derived.

2. The Classical Arabic phonetic terms were formed in several ways involving either (i) simple elements comprising one word, (ii) compound elements comprising two words, or (iii) complex elements comprising more than two words. It seems that the spread of terms consisting of one element, rather than complex or compound terms, was motivated by a desire for ease and to avoid redundancy. However, when one word was not enough to express the concept, complex or compound elements were resorted to. As a result of the development of phonetic studies from the stage of establishment in the second Hijri century to that of categorisation later, most of the complex Classical Arabic phonetic terms became compound terms, while a number of compound terms were later converted to simple terms.

3. In the vast majority of cases, Classical Arabic terms arose through two basic methods, (i) the allocation of new lexical senses, and (ii) the transition to metaphorical meanings, while translation and borrowing from other languages did not have an impact on these terms. While general lexical meanings develop spontaneously among speakers, the allocation of these meanings to the generation of terms requires prior planning and awareness among specialists in addition to accuracy and concision, as was the case with the terms for the short vowels. The transition from a literal usage to a metaphorical one leads to the liberation of speakers from the confines of the limited meanings of words through their expansion into unexpected denotations. This happened, for example, with the terms for the accepted and unaccepted allophones in these treatises which became associated with the aesthetic criteria of 'appreciated' and 'unappreciated' through a shift to metaphorical meanings.

\section{Suggestions}

The above results are the most important ones to clarify the methodology of the Classical Arabic linguistic treatises in the development of terms and areas of difference regarding them, as well as their generation and fundamental roots. These results offer original research opportunities for the study of the formulation and construction in clarifying classical Arabic phonetic concepts through definitions and the various possible positions of these definitions. These include characteristics and practical experiments, and have led to the existence of complete and incomplete definitions which explore the basic elements to distinguish between phonetic concepts, in respect of structure and development of multiple and secondary definitions.

\section{References}

Abd Al-Ğalīl, A. (1997). Al-`așwāt al-luġawiyyah. Amman: DārȘafāõ .

Al-Farāhīd̄̄, A. (2003). Kitāb al-cayn. Hindāwī, c . (Ed.). Beirut: Dār Al-kutub Al-cilmiyyah.

Al-Murādī, I. (1987). Al-mufìdfǐšarh cumdat al-mağīd. Al-Bawwāb,. c. (Ed.). Zarqā Maktabat Almanār.

Al-Rumḥ̄î, H. (2004). Al-baḥt aṣ-șawti cinda Al-Farrāo fimacānīal-Qurōann. Master's thesis, The University of Jordan.

Al-ºndalusī, A. (1998). `irtišăâf aḍ-ḍarab. Muḥammad, R. (Ed.). Beirut:DārAl-fikr Al-Lubnāni. 
Al-cubaydī, R. (2007). Mucğam aș-ṣawtiyyāt. Silsilat Al-dirāsāt Al-IslāmīyyahAl-mưāṣirah, Vol 22. Baghdad: Markāz ’albuhut wa Ad-dirasāt Al-`islamyah.

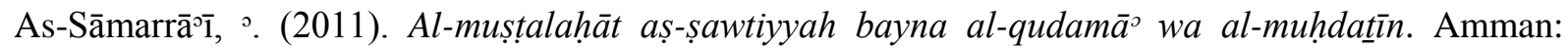
DārĞarīr.

As-Sakkākī, Y. (1987). Muftāh al-culūm. Zarzūr, N. (Ed.).Beirut: Dār Al-kutub Al-cilmiyyah.

As-Sīrāfî, A. (2008). šarḥ Kitāb Sibawayh. Mahdalī, ’ \& cAli, c. (Eds.). Beirut: Dār Al-kutub Alcilmiyyah.

Aș-Ṣiyağ, c . (2000). Al-mușțalaḥ aṣ-ṣawti fi ad-dirāsāt al-carabiyyah. Damascus: Dār Al-fikr.

As-Siyūṭ̂̄, Ğ. (2001). Ham ${ }^{c}$ al-hawāmic . Makram, A. (Ed.). Kuwait: Institute for Scientific Research.

Az-Zabīdī, M. (2001). Tāğ al-carūs min ğawāhir al-qāmūs. Hịğāzī, M. (Ed.). Kuwait: National Council for Culture, Arts and Letters.

Az-Zağğăğ̄̄i, A. (1988). Al-ğumal fi an-naḥw. Al-ḥamad, c. (Ed.). Beirut: Al-Resalah Publishing House.

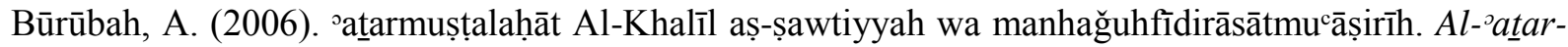
Mă̌alat al- ${ }^{\circ} \bar{a} d \bar{a} b$ wa Al-luğàt. 5(5), pp. 23-35.

Darqāwī, M. (2016). Tarāōiqtacr:bal-muștalah wa șināatat-tacrîffì ad-dars al-lisānn̄ al-carabiy alhadīt. Beirut: Dār Al-kutub Al-cilmiyyah.

Ḥiğāzī, M. (2018). Al-`usus al-lugiawiyyahlicilm al-muștalah. Cairo: Dārg̉arīb.

Ibn As-Sarrāğğ, A. (1996). Al-'ousūllfì an-naḥw. (3rd ed.). Al-Fatlī, A. (Ed.). Beirut: Al-Resalah Publishing House.

Ibn Manẓūr, M. (2003). Lisān al-carab. Beirut: DārȘādir.

Ibn Yacī̌s, A. (2001). šarḥal-Mufașșal. Yacqūb, ’. (Ed.). Beirut: Dār Al-kutub Al-cilmiyyah.

Ibn Yač̄̌š, A. (2001). šarhal-Mufașșal. Yacaūb, ’. (Ed.). Beirut: Dār Al-kutub Al-cilmiyyah.

Khālidī, H. (2012). Șinācat al-mușțalaḥ aș-ṣawtīfí al-lisān al-carabī al-ḥadīt. Beirut: Dār Al-kutub Alcilmiyyah.

Sibawayh, A. (2015). Kitāb Sibawayh. Al-Bakkā, M. (Ed.). Beirut: Zein Legal Publications.

Troupeau, G. (1982). Na`at an-naћw al-carabīfìdawº kita:b Sibawayh. The Journal of Jordan Academy of Arabic, 1(1), pp. 125-138.

Zawāqirī, c . (2017). Al-muș̣talaḥ aṣ-șawtī bayna at-turāt wa at-tağdīd. Ph.D. thesis, University of Batna.

'Uțmān, R. (2010). Al-mușțalaḥ an-naḥwī wa a aṣal ad-dalālah. Beirut: Dār Al-kutub Al-cllmiyyah.

Alwin, D.F. \& McCammon, R.J. (2007). Rethinking generations. Research in Human Development, 4(3-4), pp.219-237.

Bauer, L. (2003). Introducing linguistic morphology. (2nd ed.). Washington DC: Georgetown University Press.

Colless, D.H. (1967). An examination of certain concepts in phenetic taxonomy. Systematic Zoology, 16(1), pp. 6-27. 
Fleisch, H. (1961). Traité de philologiearabe. vol.1: préliminaires, phonétiquemorphologienominale. Beirut: Imprmerie Catholique.

Gibbs Jr, R.W. (2001). Evaluating contemporary models of figurative language understanding. Metaphor and symbol, 16(3-4), pp. 317-333.

Giora, R. (2002). Literal vs. figurative language: different or equal?. Journal of pragmatics, 34(4), pp. 487-506.

Grondelaers, S. \& Geeraerts, D. (2003). Towards a pragmatic model of cognitive onomasiology. In: Cuyckens, H., Dirven, R. and Taylor, J.R. eds. Cognitive approaches to lexical semantics. Berlin: Mouton de Gruyter, pp. 67-92.

Johnson, K. (2011). Acoustic and auditory phonetics. John Wiley \& Sons.

Jones, D. (1976). An outline of English phonetics. Cambridge: Cambridge University Press.

Karpova, O. \& Kartashkova, F. (Eds.). (2009). Lexicography and terminology: a worldwide outlook. Newcastle upon Tyne: Cambridge Scholars Publishing.

Kilgarriff, A. (2007). Word senses. In: Agirre, E. \& Edmonds, P. (Eds.). Word sense disambiguation. Oxford: Springer, pp. 29-46.

Kockaert, H.J. \& Steurs, F. (Eds.). (2015). Handbook of terminology. Amsterdam: John Benjamins.

Laprie, J.C. (Ed.). (1992). Dependability: basic concepts and terminology. Dependable computing and fault-tolerant systems, Vol 5. Vienna: Springer-Verlag.

Meyer, I., Eck, K. \& Skuce, D. (1997). Systematic concept analysis within a knowledge-based approach to terminology. Wright, S.E. and Budin, G. eds. Handbook of Terminology Management: Basic Aspects of Terminology management, 1. Amsterdam: John Benjamins, pp. 98119.

Murphy, M.L. (2003). Semantic relations and the lexicon: antonymy, synonymy and other paradigms. Cambridge: Cambridge University Press.

Pinker, S. \& Levin, B. (Ed.). (1991). Lexical and conceptual semantics. Amsterdam: Elsevier.

Plag, I. 2012. Morphological productivity: structural constraints in English derivation. Kortmann, B. and Traugott, E.C. (Eds.). Berlin: Walter de Gruyter.

Ramchand, G. \& Svenonius, P. (2002). The lexical syntax and lexical semantics of the verb-particle construction. In: L. Mikkelsen and C. Potts. (Eds.). WCCFL 21 Proceedings, April 2002, Santa Cruz. Massachusetts: Cascadilla Press, pp. 387-400.

Rey, A. (1995). Essays on terminology. Amsterdam: John Benjamins.

Sager, J.C. (1990). Practical course in terminology processing. Amsterdam: John Benjamins.

Uschold, M. (1998). Knowledge level modelling: concepts and terminology. The knowledge engineering review, 13(1), pp. 5-29.

Vallaro, M. (1987). La hamzat bayna bayna secondo i grammatici Arabi. Oriente Moderno, 67(7-12), pp. 215-221.

Versteegh, C.H.M. (1993). Arabic grammar and Qur'ānic exegesis in early Islam. Leiden: Brill.

Versteegh, C.H.M. (1977). Greek elements in Arabic linguistic thinking, 7. Leiden: Brill. 
Wang, Y.D. \& Emurian, H.H. (2005). An overview of online trust: Concepts, elements, and implications. Computers in human behavior, 21(1), pp. 105-125.

Watson, J.C. (2002). The phonology and morphology of Arabic. Oxford: Oxford University Press.

Wehr, H. (1979). A dictionary of modern written Arabic. Cowan, J.M. (Ed.). Wiesbaden: Otto Harrassowitz.

\section{AUTHOR BIODATA}

Hamood Mohammed Alrumhi is a lecturer at Sultan Qaboos University, College of Arts and Social Sciences. He has a master's degree in linguistics from The University of Jordan, Jordan. Currently, he is a Ph.D. researcher at the University of Leeds, Department of Linguistics and Phonetics. He has presented and published in the subject of phonetics and phonology. 